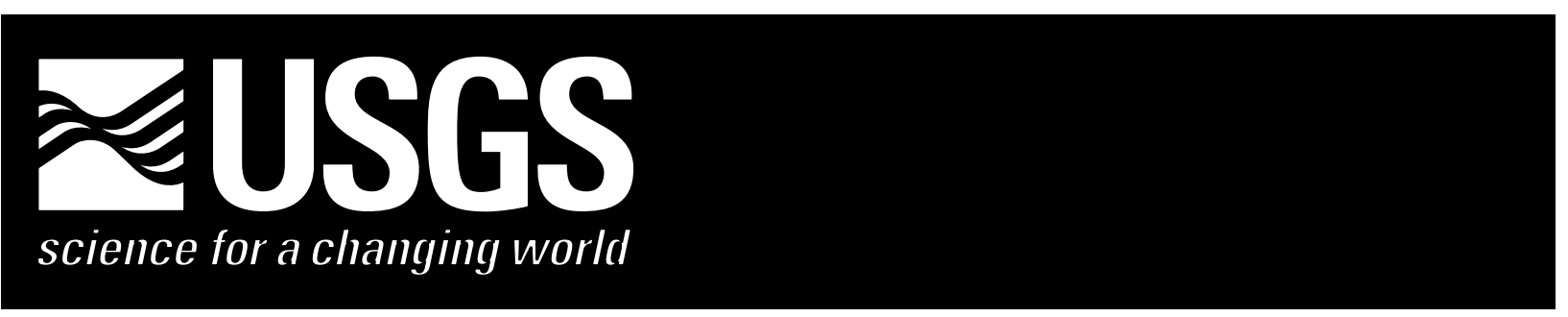

\title{
PUBLICATIONS OF THE WESTERN GEOLOGIC MAPPING TEAM 1997-1998
}

Compiled by Paul Stone ${ }^{1}$ and Charles L. Powell, II

Open-File Report 99-302

1999

This report is preliminary and has not been reviewed for conformity with U.S. Geological Survey editorial standards or with the North American Stratigraphic Code. Any use of trade, firm, or product names is for descriptive purposes only and does not imply endorsement by the U.S. Government.

\section{U. S. DEPARTMENT OF THE INTERIOR \\ U. S. GEOLOGICAL SURVEY}

${ }^{1}$ U. S. Geological Survey, 345 Middlefield Road, Menlo Park, CA 94025 


\section{INTRODUCTION}

The Western Geologic Mapping Team (WGMT) of the U.S. Geological Survey, Geologic Division (USGS, GD), conducts geologic mapping and related topical earthscience studies in the western United States. This work is focused on areas where modern geologic maps and associated earth-science data are needed to address key societal and environmental issues such as ground-water quality, potential geologic hazards, and land-use decisions. Areas of primary emphasis currently include southern California, the San Francisco Bay region, the Pacific Northwest, the Las Vegas urban corridor, and selected National Park lands. The team has its headquarters in Menlo Park, California, and maintains smaller field offices at several other locations in the western United States.

The results of research conducted by the WGMT are released to the public as a variety of databases, maps, text reports, and abstracts, both through the internal publication system of the USGS and in diverse external publications such as scientific journals and books. This report lists publications of the WGMT released in calendar years 1997 and 1998. Most of the publications listed were authored or coauthored by WGMT staff. However, the list also includes some publications authored by formal non-USGS cooperators with the WGMT, as well as some authored by USGS staff outside the WGMT in cooperation with WGMT projects.

Several of the publications listed are available on the World Wide Web; for these, URL addresses are provided. Most of these Web publications are USGS open-file reports that contain large digital databases of geologic map and related information. For these, the bibliographic citation refers specifically to an explanatory pamphlet containing information about the content and accessibility of the database, not to the actual map or related information comprising the database itself.

Information on ordering USGS publications can be found on the World Wide Web at <http://www-nmd.usgs.gov/esic/to_order.html>, or by calling 1-800-HELP-MAP. The U.S. Geological Survey's web server for geologic information in the western United States is located at <http://geology.wr.usgs.gov/>.

\section{PUBLICATIONS}

Abbott, L.D., Silver, E.A., Anderson, R.S., Smith, R., Ingle, J.C., Kling, S.A., Haig, D., Small, E., Galewsky, J., and Sliter, W.V., 1997, Measurement of tectonic surface uplift rate in a young collisional mountain belt: Nature, v. 385 , no. 6616, p. 501507.

Aiello, I.W., and Hagstrum, J.T., 1997, Paleomagnetism of Middle to Upper Jurassic radiolarian cherts above the continental margin of the Western Tethys (Adria): first data from Tuscan Cherts, Northern Apennines, Italy [abs.]: INTERRAD VIII, Abstracts, p. 4. 
Aitken, D.S., 1997, A digital version of the 1970 U.S. Geological Survey topographic map of the San Francisco Bay region, three sheets, 1:125,000: U.S. Geological Survey Open-file Report 97-500, 11 p., $<$ http://wrgis.wr.usgs.gov/open-file/of97-500/index.html>.

Alexeiev, D.V., Cook, H.E., Buvtyshkin, V.M., Golub, L.Ya., and Zhaimina, V.Ya., 1997, Dynamics of Late Paleozoic collisions at the southwestern margin of the Kazakstania paleocontinent: new evidence from the Bolshoi Karatau Mountains (northwestern Tien Shan): European Union of Geosciences, Abstract Supplement No 1, Terra Nova Volume 9, 1977, p. 345.

Barth, A.P, Tosdal, R.M., Wooden, J.L., and Howard, K.A., 1997, Triassic plutonism in southern California: southward younging of arc initiation along a truncated continental margin: Tectonics, v. 16, no. 2, p. 290-304.

Beard, L.S., Block, D., Aldrich, M., and Kaye, A., 1997, A digital geologic and geophysical database for the Lake Mead region, southeastern Nevada: data sources, database creation, and preliminary analysis using GIS [abs.]: Geological Society of America Abstracts with Programs, v. 29, no. 6, p. A-293.

Benson, L.V., Smoot, J.P., Kashgarian, M., Sarna-Wojcicki, A.M., and Burdett, J.W., 1997, Radiocarbon ages and environments of deposition of the Wono and Trego Hot Springs tephra layers in the Pyramid Lake Subbasin, Nevada: Quaternary Research, v. 47, no. 3, p. 251-260.

Billingsley, G.H., 1997, Geologic map of the Mount Logan quadrangle, northern Mohave County, Arizona: U.S. Geological Survey Open-file Report 97-426, 21 p., scale $1: 24,000$.

Billingsley, G.H., 1997, Geologic map of the Mount Trumbull NW quadrangle, northern Mohave County, Arizona: U.S. Geological Survey Open-file Report 97-488, 19 p., scale 1:24,000.

Billingsley, G.H., 1997, Geologic map of the Poverty Springs quadrangle, northern Mohave County, Arizona: U.S. Geological Survey Open-file Report 97-493, 13 p., scale 1:24,000.

Billingsley, G.H., 1997, The Permian clastic sedimentary rocks of northwestern Arizona, chap. F of Maldonado, F., and Nealey, L.D., eds., Geologic studies in the Basin and Range-Colorado Plateau transition in southeastern Nevada, southwestern Utah, and northwestern Arizona, 1995: U.S. Geological Survey Bulletin 2153, p. 109-124.

Billingsley, G.H., and Workman, J.B., 1997, New digital geologic map of the Littlefield $30 \times 60$ ' quadrangle, Mohave County, northwestern Arizona [abs.]: Geological Society of America Abstracts with Programs, v. 29, no. 6, p. A-305. 
Blakely, R.J., Christiansen, R.L., Guffanti, M.C., Wells, R.E., Donnelly-Nolan, J.M., Muffler, L.J.P., Clynne, M.A., and Smith, J.G., 1997, Gravity anomalies, Quaternary vents, and Quaternary faults in the southern Cascade Range, Oregon and California: implications for arc and backarc evolution: Journal of Geophysical Research v. 102, no. B10, p. 22,513-22,527.

Blakely, R.J., Cruikshank, K., Johnson, A., Beeson, M., Walsh, K., and Wells, R.E., 1997, A gravity study through the Tualatin Mountains, Oregon: understanding crustal structure and earthquake hazards in the Portland urban area [abs.]: Geological Society of America Abstracts with Programs, v. 29, no. 5, p. 5.

Blakely, R.J., and McLaughlin, R.J., 1997, The Geysers geothermal reservoir, California: constraints from high-resolution aeromagnetic anomalies [abs.]: Geological Society of America Abstracts with Programs, v. 29, no. 5, p. 5.

Brabb, E.E., 1997, Geologic map of Santa Cruz County, California: a digital database: U.S. Geological Survey Open-file Report 97-489, 15 p., <http://wrgis.wr.usgs.gov/open-file/of97-489/index.html>.

Brocher, T.M., Brabb, E.E., Catchings, R.D., Fuis, G.S., Fumal, T.E., Jachens, R.C., Jayko, A.S., Kayen, R.E., McLaughlin, R.J., Parsons, T., Rymer, M.J., Stanley, R.G., and Wentworth, C.M., 1997, A crustal-scale 3-D seismic velocity model for the San Francisco Bay Area, California [abs.]: Eos, Transactions, American Geophysical Union, v. 78, no. 46, supplement, p. F435-436.

Carr, M.D., Christiansen, R.L., Poole, F.G., and Goodge, J.W., 1997, Bedrock geologic map of the El Paso Mountains in the Garlock and El Paso Peaks 7-1/2' quadrangles, Kern County, California: U.S. Geological Survey Miscellaneous Investigations Series Map I-2389, scale 1:24,000.

Clark, J.C., and Brabb, E.E., 1997, Geology of Point Reyes National Seashore and vicinity, California: a digital database: U.S. Geological Survey Open-file Report 97-456, 17 p., <http://wrgis.wr.usgs.gov/open-file/of97-456/index.html>.

Clark, J.C., Dupre, W.R., and Rosenberg, L.I., 1997, Geologic map of the Monterey and Seaside 7.5' quadrangles, Monterey County, California: a digital database: U.S. Geological Survey Open-file Report 97-30, 15 p., <http://wrgis.wr.usgs.gov/open-file/of97-30/index.html>.

Cook, H.E., Zempolich, W.G., Zhemchuzhnikov, V.G., and Corboy, J., 1997, Inside Kazakstan: cooperative oil and gas research: Geotimes, v. 42, no. 11, p. 16-20.

Cook, H.E., Zhemchuzhnikov, V.G., Zempolich, W.G., Lehmann, P.J., Zhaimina, V.Ya., Buvtyshkin, V.M., Golub, L.Ya., Bowman, M., Fretwell, P.N., Lapointe, P.A., Giovannelli, A., and Viaggi, M., 1997, Carbonate platform facies in the Karatau of S. Kazakstan: outcrop analogs for carbonate fields in the N. Caspian Basin, W. Kazakstan [abs.]: 1997 AAPG Annual Convention, Official Program, v. 6, p. A22. 
Cook, H.E., Zhemchuzhnikov, V.G., Zempolich, W.G., Zhaimina, V.Ya., Lehmann, P.J., Lapointe Ph.A., and Buvtyshkin, V.M., 1997, Devonian and Carboniferous carbonate platforms in the Karatau of S. Kazakstan: outcrop analogs for coeval carbonate reservoirs in the N. Caspian Basin [abs.]: American Association of Petroleum Geologists Bulletin, v. 81, no. 8, p. 1367-1368.

Cox, B.F., 1997, Geologic investigations along Mojave River, California, from Lower Narrows to Bryman: U.S. Geological Survey Administrative Report, 8 p.

Densmore, J.N., Cox, B.F., and Crawford, S.M., 1997, Geohydrology and water quality of Marine Corps Logistics Base, Nebo and Yermo Annexes, near Barstow, California: U.S. Geological Survey Water-Resources Investigations Report 96$4301,116 \mathrm{p}$.

El Niño Response Group (Cannon, S.H., Ellen, S.D., Graham, S.E., Graymer, R.W., Hampton, M.A., Hillhouse, J.W., Howell, D.G., Jayko, A.S., LaHusen, R.L., Lajoie, K.R., Pike, R.J., Ramsey, D.W., Reid, M.E., Richmond, B.M., Savage, W.Z., Wentworth, C.M., and Wilson, R.C.), 1997, Slope failure and shoreline retreat during California's latest El Niño: GSA Today, v. 8, no. 8, p. 1-6.

Ellen, S.D., Mark, R.K., Wieczorek, G.F., Wentworth, C.M., Ramsey, D.W., and May, T.E., 1997, Map showing principal debris-flow source areas in the San Francisco Bay region, California: U.S. Geological Survey Open-file Report 97-745-E, 8 p., $<$ http://wrgis.wr.usgs.gov/open-file/of97-745/index.html>.

Fleck, R.J., Wooden, J.L., Matti, J.C., Powell, R.E., and Miller, F.K., 1997, Geochronologic investigations in the Little San Bernardino Mountains, California [abs.]: Geological Society of America Abstracts with Programs, v. 29, no. 5, p. 12-13.

Fretwell, P.N., Hunt, D., Craik, D., Cook, H.E., Lehmann, P.J., Zempolich, W.G., Zhemchuzhnikov, V.G., and Zhaimina, V.Ya., 1997, Prediction of the spatial variability of diagenesis and porosity using sequence stratigraphy in Middle Carboniferous carbonates from southern Kazakstan: implications for North Caspian Basin hydrocarbon reservoirs of the C.I.S. [abs.]: 1997 AAPG Annual Convention, Official Program, v. 6, p. A37-38.

Glazner, A.F., and Miller, D.M., 1997, Late-stage sinking of plutons: Geology, v. 25, no. 12, p. 1099-1102.

Graham, S.E., and Pike, R.J., 1997, Shaded relief map of the San Francisco Bay region, California: U.S. Geological Survey Open-file Report 97-745-B, 8 p., <http://wrgis.wr.usgs.gov/open-file/of97-745/index.html>.

Graymer, R.W., 1997, Geology of the southernmost part of Santa Clara County, California: a digital database: U.S. Geological Survey Open-file Report 97-710, 11 p., <http://wrgis.wr.usgs.gov/open-file/of97-710/index.html>. 
Grommé, S., Deino, A.M., Best, M.G., and Hudson, M.R., 1997, Geochronologic and paleomagnetic evidence defining the relationship between the Miocene Hiko and Racer Canyon tuffs, eccentric outflow lobes from the Caliente caldera complex, southeastern Great Basin, USA: Bulletin of Volcanology, v. 59, no. 1, p. 21-35.

Grommé, S., and Hillhouse, J.W., 1997, Paleomagnetic results from Devonian and Permian rocks at Saginaw Bay, Kuiu Island, southeastern Alaska, in Dumoulin, J., and Gray, J., eds., Geologic studies in Alaska by the U.S. Geological Survey, 1995: U.S. Geological Survey Professional Paper 1574, p. 295-306.

Hagstrum, J.T., 1997, Paleomagnetism, paleogeographic origins, and remagnetization of the Coast Range Ophiolite and Great Valley sequence, Alta and Baja California [abs.]: American Association of Petroleum Geologists Bulletin, v. 81, no. 4 , p. 686-687.

Haugerud, R.A., 1997, Flexible map production from a digital composite geologic-map database [abs.]: Geological Society of America Abstracts with Programs, v. 29, no. 6 , p. A-306.

Haugerud, R.A., 1997, The North America Cordillera: a map for the study of active tectonics [abs.]: Geological Society of America Abstracts with Programs, v. 29, no. 5, p. 19.

Haugerud, R.A., and Tabor, R.W., 1997, Fast, easy, and accurate digital geologic maps: a composite map of the North Cascades, Washington [abs.]: Geological Society of America Abstracts with Programs, v. 29, no. 6, p. A-306.

Helley, E.J., and Graymer, R.W., 1997, Quaternary geology of Alameda County, and parts of Contra Costa, Santa Clara, San Mateo, San Francisco, Stanislaus, and San Joaquin Counties, California: a digital database: U.S. Geological Survey Open-file Report 97-97, 13 p., $<$ http://wrgis.wr.usgs.gov/open-file/of97-97/index.html>. .

Helley, E.J., and Graymer, R.W., 1997, Quaternary geology of Contra Costa County, and surrounding parts of Alameda, Marin, Sonoma, Solano, Sacramento, and San Joaquin Counties, California: a digital database: U.S. Geological Survey Open-file Report 97-98, 13 p., <http://wrgis.wr.usgs.gov/open-file/of97-98/index.html>.

Hereford, R., Thompson, K.S., and Burke, K.J., 1997, Dating prehistoric tributary debris fans, Colorado River, Grand Canyon National Park, Arizona, with implications for channel evolution and river navigability: U.S. Geological Survey Open-file Report 97-167, $17 \mathrm{p}$.

Hildenbrand, T., Blakely, R., Jachens, R., and Saltus, R., 1997, Insights on crustal structures based on new regional magnetic anomaly data in western U.S.A. [abs.]: Eos, Transactions, American Geophysical Union, v. 78, no. 17, supplement, p. S118. 
Hillhouse, J.W., 1997, Magnetic stratigraphy of Plio-Pleistocene sediments of the Los Angeles Basin, California [abs.]: American Association of Petroleum Geoloigsts Bulletin, v. 81, no. 4, p. 687.

Hillhouse, J.W., and Cox, B.F., 1997, Magnetic stratigraphy of boreholes 6M2MW7 and 6M36MW8 at March Air Force Base, California: U.S. Geological Survey Openfile Report 97-862, 64 p.

Hillhouse, J.W., and Jachens, R.C., 1997, Highly magnetic sandstones of the San Francisco Bay area, California [abs.], in Bostrom, R., and others, eds., Abstracts, 8th Scientific Assembly of IAGA with ICMA and STP Symposia, p. 80.

Howard, K.A., 1997, High-level gravel near Lake Mead: evidence for an outburst flood from the Grand Canyon? [abs.]: Geological Society of America Abstracts with Programs, v. 29, no. 6, p. A-316.

Howard, K.A., Dennis, M.L., Karlstom, K., and Phelps, G.A., 1997, Preliminary geologic map of the Little Piute Mountains, San Bernardino County, California: a digital database: U.S. Geological Survey Open-file Report 97-693, 14 p., <http://wrgis.wr.usgs.gov/open-file/of97-693/index.html>.

Howard, K.A., and Hopson, R.F., 1997, Vertical axis rotations in the Mojave: evidence from the Independence Dike swarm: Comment: Geology, v. 25, no. 11, p. 10511052.

Howard, K.A., and John, B.E., 1997, Fault-related folding during extension: plunging basement-cored folds in the Basin and Range: Geology, v. 25, no. 3, p. 223226.

Howard, K.A., John, B.E., and Nielson, J.E., 1997, Preliminary geologic map of the eastern and northern parts of the Topock 7.5-minute quadrangle, Arizona and California: U.S. Geological Survey Open-file Report 95-534, 23 p., scale $1: 24,000$.

Jachens, R.C., Howell, D.G., Wentworth, C.M., Chan, C.S., and Roberts, M.A., 1997, Presentation of three-dimensional geologic data [abs.]: Geological Society of America Abstracts with Programs, v. 29, no. 6, p. A-424.

Jachens, R.C., Sikora, R.F., and Brabb, E.E., 1997, The basement interface: San Francisco Bay area, California, 3-D seismic velocity model [abs.]: Eos, Transactions, American Geophysical Union, v. 78, no. 46, supplement, p. F436.

Jayko, A.S., 1997, Digital geomorphic investigation, in U.S. Geological Survey, ed., Investigation of the San Bruno fault near the proposed extension of the Bay Area Rapid Transit line from Colma to San Francisco International Airport, San Mateo County, California: U.S. Geological Survey Open-file Report 97-429, p. 26-55. 
Jayko, A.S., 1997, Reconnaissance geologic map of the Dodson Butte 7.5' quadrangle, Oregon: U.S. Geological Survey Open-file Report 97-514, 12 p., scale 1:24,000.

Jayko, A.S., 1997, Shallow subsurface geometry of seismic velocity interfaces for 3-D modeling, and magnitudes of Cenozoic crustal strain, San Francisco Bay region, California [abs.]: Eos, Transactions, American Geophysical Union, v. 78, no. 46, supplement, p. F436.

Jayko, A.S., and Gallager, M., 1997, Reconnaissance geologic map of the Myrtle Creek 7.5' quadangle, Oregon: U.S. Geological Survey Open-file Report 97-527, 10 p., scale 1:24,000.

Jayko, A.S., Platz, M., Scharer, K., and Green Nylen, N., 1997, Characteristics of late Cenozoic folding associated with strike-slip faulting, San Francisco Bay region, California [abs.]: Geological Society of America Abstracts with Programs, v. 29, no. 6, p. A-235.

Johnson, K., Barnes, C.G., Wright, J.E., Kistler, R.W., Walton, C., and Karlsson, H.R., 1997, Isotope systematics of Jurassic and Cretaceous plutons west of the 0.706 line in the Blue Mountains, northeastern Oregon [abs.]: Geological Society of America Abstracts with Programs, v. 29, no. 6, p. A-456.

Kistler, R.W., 1997, Granitoid intrusive suite in the Salinian composite terrane of coastal California [abs.]: Geological Society of America Abstracts with Programs, v. 29, no. 6 , p. A-68.

Kistler, R.W., and Champion, D.E., 1997, Ages of hornblende and biotite from plutons in the Salinian block, coastal California [abs.]: Geological Society of America Abstracts with Programs, v. 29, no. 5, p. 22.

Knott, J.R., Sarna-Wojcicki, A.M., Montanez, I.P., and Geissman, J.W., 1997, Differentiating the upper Pliocene Mesquite Spring tuffs from the middle Pleistocene Bishop ash bed, Death Valley, California: implications for reliable correlations of the Bishop ash bed [abs.]: Eos, Transactions, American Geophysical Union, v. 78, no. 46, supplement, p. F760.

Knudsen, K.L., Noller, J.S., Sowers, J.M., and Lettis, W.R., 1997, Quaternary geology and liquefaction susceptibility, San Francisco, California 1:100,000 quadrangle: a digital database: U.S. Geological Survey Open File Report 97-715, 19 p., <http://wrgis.wr.usgs.gov/open-file/of97-715/index.html>

Langenheim, V.E., and Jachens, R.C., 1997, Aeromagnetic map of the Los Angeles 1:100,000-scale quadrangle, California: U.S. Geological Survey Open-file Report 97-162, scale 1:100,000.

Langenheim, V.E., Jachens, R.C., Chuchel, B.A., and Dixon, G.L., 1997, Mapping the subsurface in the Las Vegas and Lake Mead 1:100,000-scale quadrangles, Nevada and Arizona [abs.]: Geological Society of America Abstracts with Programs, v. 29, no. 6, p. A-305. 
Langenheim, V.E., Jachens, R.C., and Schmidt, K.M. , 1997, Preliminary location and geometry of the Las Vegas Valley Shear Zone based on gravity and aeromagnetic data: U.S. Geological Survey Open-file Report 97-441, 25 p.

Langenheim, V.E., Schmidt, K.M., and Jachens, R.C., 1997, Coseismic deformation during the 1989 Loma Prieta earthquake and range-front thrusting along the southwestern margin of the Santa Clara Valley, California: Geology, v. 25, no. 12, p. 1091-1094.

Langenheim, V.E., Stiles, S.R., Jachens, R.C., and Jewel, E.B., 1997, Geometry of the San Andreas Fault inferred from gravity and aeromagnetic data, south of Hollister, California [abs.]: Eos, Transactions, American Geophysical Union, v. 78 , no. 46 , supplement, p. F454.

Lapointe, Ph.A., Bernet-Rollande, M.C., Zhemchuzhnikov, V.G., Cook, H.E., Zempolich, W.G., and Lehmann, P.J., 1997, Evaporite collapse breccia versus karst breccia: the Upper Devonian-Lower Carboniferous Balaturlan unit, Bolshoi Karatau Mountains, southern Kazakstan [abs.]: American Association of Petroleum Geologists Bulletin, v. 81, no. 8, p. 1393.

MacCready, T., Snoke, A.W., Wright, J.E., and Howard, K.A., 1997, Mid-crustal flow during Tertiary extension in the Ruby Mountains core complex, Nevada: Geological Society of America Bulletin, v. 109, no. 12, p. 1576-1594.

Matti, J.C., Miller, F.K., Powell, R.E., Kennedy, S.A., Bunyapanasarn, T.P., Koukladas, C., Hauser, R.M., and Cosette, P.M., 1997, Geologic point attributes for digital geologic-map data bases produced by the Southern California Areal Mapping Project (SCAMP), version 1.0: U.S. Geological Survey Open-file Report 97-859, $51 \mathrm{p}$.

Matti, J.C., Miller, F.K., Powell, R.E., Kennedy, S.A., and Cosette, P.M., 1997, Geologic polygon attributes for digital geologic-map data bases produced by the Southern California Areal Mapping Project (SCAMP), version 1.0: U.S. Geological Survey Open-file Report 97-860, $179 \mathrm{p}$.

Matti, J.C., Powell, R.E., Miller, F.K., Kennedy, S.A., Ruppert, K.R., Morton, G.L., and Cosette, P.M., 1997, Geologic line attributes for digital geologic-map data bases produced by the Southern California Areal Mapping Project (SCAMP), version 1.0: U.S. Geological Survey Open-file Report 97-861, 103 p.

McKee, E.H, 1997, Evaluation of geologic structure guiding ground water flow south and west of Frenchman Flat, Nevada Test Site: U.S. Geological Survey Openfile Report 97-734, 26 p.

McLaughlin, R.J., Jachens, R.C., Stanley, R.G., Jayko, A.S., Langenheim, V.E., Wentworth, C.M., and McDougall, K.A., 1997, Neogene transpressional and extensional tectonism northeast of the San Andreas fault, southwestern Santa 
Clara Valley, CA [abs.]: Geological Society of America Abstracts with Programs, v. 29 , no. 5 , p. 28 and 53.

McLaughlin, R.J., Langenheim, V.E., Jachens, R.C., Jayko, A.S., Stanley, R.G., Valin, Z., and Schmidt, K.M., 1997, Neogene transpressional range-front deformation, southwestern Silicon Valley, San Francisco Bay region, California [abs.]: Eos, Transactions, American Geophysical Union, v. 78, no. 46, supplement, p. F426.

Miller, D.M., 1997, Geologic map of the Locomotive Springs quadrangle, Box Elder County, Utah: Utah Geological Survey Open-File Map OFR 349, scale 1:24,000.

Miller, D.M., 1997, Geologic map of the Monument Peak NE quadrangle, Box Elder County, Utah: Utah Geological Survey Open-File Map OFR 346, scale 1:24,000.

Miller, D.M., 1997, Geologic map of the Monument Peak NW quadrangle, Box Elder County, Utah: Utah Geological Survey Open-File Map OFR 345, scale 1:24,000.

Miller, D.M., Armstrong, R.L., Davis, M., Wells, M.L., and Struthers, J., 1997, Stoping and extensional deformation in a metamorphic core complex, Almo Pluton, City of Rocks National Reserve, southern Idaho [abs.]: Geological Society of America Abstracts with Programs, v. 29, no. 6, p. A-348.

Miller, D.M., and Langrock, H., 1997, Geologic map of the Monument Peak quadrangle, Box Elder County, Utah: Utah Geological Survey Open-File Map OFR 344, scale 1:24,000.

Miller, D.M., and Langrock, H., 1997, Geologic map of the Monument Peak SW quadrangle, Box Elder County, Utah: Utah Geological Survey Open-File Map OFR 347, scale 1:24,000.

Miller, D.M., and Langrock, H., 1997, Geologic map of the Monument Point quadrangle, Box Elder County, Utah: Utah Geological Survey Open-File Map OFR 348, scale 1:24,000.

Moreno, M., McGann, M., Sloan, D., and Cohen, A.N., 1997, West coast distribution of the introduced Japanese Foraminifer Trochammina hadai [abs.]: Geological Society of America Abstracts with Programs, v. 29, no. 6, p. A95.

Morton, D.M., and Kistler, R.W., 1997, SRI variation in the northern Peninsular Ranges batholith [abs.]: Geological Society of America Abstracts with Programs, v. 29, no. 6 , p. A-69.

Murchey, B.L., and Hagstrum, J.T., 1997, Paleomagnetism of Jurassic radiolarian chert above the Coast Range ophiolite at Stanley Mountain, California, and implications for its paleogeographic origins: Reply: Geological Society of America Bulletin, v. 109, no. 12, p. 1633-1639. 
Nielson, J.E., and Beratan, K.I., 1997, Model of episodic extensional faulting, Colorado River corridor, CA and AZ, based on Miocene stratigraphy and structure [abs.]: Geological Society of America Abstracts with Programs, v. 29, no. 6, p. A376.

O'Connor, J.E., Wozniak, K.C., Gannett, M.W., and Sarna-Wojcicki, A.M., 1997, Late Quaternary geology of the Williamette Valley, Oregon [abs.]: Geological Society of America Abstracts with Programs, v. 29, no. 6, p. A-34.

Pike, R.J., 1997, Index to detailed maps of landslides in the San Francisco Bay region, California: U.S. Geological Survey Open-file Report 97-745-D, 20 p., $<$ http://wrgis.wr.usgs.gov/open-file/of97-745/index.html>.

Pike, R.J., and Howell, D.G., 1997, Impact of USGS research in the greater San Francisco Bay area-report on Western Region Forum, March 13 and 14, 1997: U.S. Geological Survey Administrative Report, 24 p.

Ponce, D.A., 1997, Gravity data of Nevada: U.S. Geological Survey Digital Data Series DDS-42, CD-ROM.

Ponce, D.A., 1997, Mapping the Humboldt River basin using gravity and magnetic methods, Winnemucca 1- by 2-degree quadrangle, northern Nevada [abs.]: Geological Society of America Abstracts with Programs, v. 29, no. 6, p. A-304.

Powell, C.L., II, 1997, A record of the inarticulate brachiopod Glottidia from the ancestral Gulf of California (Miocene to Pliocene Imperial Formation), southern California: U.S. Geological Survey Open-file Report 97-538, 7 p.

Reheis, M.C., Reynolds, R.L., Sarna-Wojcicki, A.M., and Repenning, C.A., 1997, Ages of pre-late Pleistocene deep-lake cycles of Lake Lahontan [abs.]: Geological Society of America Abstracts with Programs, v. 29, no. 6, p. A-437.

Reubel, A.L., Brocher, T.M., Brabb, E.E., Fumal, T.E., Jachens, R.C., and Stanley, R.G., 1997, Compilation of sonic and density logs from oil test wells within Tertiary basins in the San Francisco Bay area, California [abs.]: Eos, Transactions, American Geophysical Union, v. 78, no. 46, supplement, p. F436.

Ridley, I., Lichte, F.E., Kistler, R., and Morton, D.M., 1997, Trace element and isotope geochemistry of the Southern California batholith: new data for the northern Peninsular and Transverse Ranges [abs.]: Geological Society of America Abstracts with Programs, v. 29, no. 6. p. A-68-69.

Roberts, C.W., 1997, Densities of well samples from the Clear Lake-Geysers area, Lake and Sonoma Counties, California: U.S. Geological Survey Open-file Report 97-427, 8 p.

Romanyuk, T.V., Mooney, W.D., and Blakely, R.J., 1997, The Cascadia subduction zone: two constrasting models of lithospheric structure [abs.]: Eos, Transactions, American Geophysical Union, v. 78, no. 46, supplement, p. F717. 
Rowan, E.L., 1997, Basin evolution and the timing and extent of oil generation, Canning River region, North Slope, Alaska: preliminary Basin2 calculations assuming a conductive thermal history: U.S. Geological Survey Open-file Report 97-711, 32 p.

San Francisco Bay Landslide Mapping Team, 1997, Introduction to the San Francisco Bay region, California, landslide folio: U.S. Geological Survey Open-file Report 97-745-A, 16 p., <http://wrgis.wr.usgs.gov/open-file/of97-745/index.html>.

Sanjines, O., Cunningham, C.G., Tavera, F., Zartman, R.E., McKee, E.H., Rye, R.O., Naeser, C.W., and Ericksen, G.E., 1997, Cerro Rico de Potosi-Bolivia, edad y temperatura de formacion: VIII Congreso Geologico Chileno Actas, v. III, Antofagasta, Chile, 13-17 Octubre, 1997, p. 1144-1147.

Sarna-Wojcicki, A.M., Meyer, C.E., and Wan, E., 1997, Age and correlation of tephra layers, position of the Matuyama-Brunhes chron boundary, and effects of Bishop ash eruption on Owens lake, as determined from drill hole OL-92, southeast California, in Smith, G.I., and Bischoff, J.L., eds., An 800,000-year paleoclimatic record from Core OL-92, Owens Lake, southeast California: Geological Society of America Special Paper 317, p. 79-90.

Silva, I.P., and Sliter, W.V., 1997, Cretaceous paleoceanography: evidence from planktonic foraminiferal evolution [abs.], in Development of paleoceanography as a new field of science, commemorating the 50th Anniversary of the Albatross Expedition 1947-1948: Royal Swedish Academy of Sciences, Stockholm and Goeteborg, August 18-21, 1997, Abstract Volume, p. 85.

Silva, I.P., and Sliter, W.V., 1997, Cretaceous paleoceanography: evidence for planktonic foraminiferal evolution [abs.]: European Union of Geosciences, Strasbourg, France, March 23-27, 1997, Abstract Supplement 1, p. 615.

Snoke, A.W., Howard, K.A., McGrew, A.J., Burton, B.R., Barnes, C.G., Peters, M.T., and Wright, J.E., 1997, The grand tour of the Ruby-East Humboldt metamorphic core complex, northeastern Nevada: part 1-introduction and road log, in Link, P.K., and Kowallis, B.J., eds., Proterozoic to Recent stratigraphy, tectonics, and volcanology, Utah, Nevada, southern Idaho, and central Mexico: Brigham Young University Geology Studies, v. 42, part 1, p. 225-269.

Stevens, C.H., Stone, P., Dunne, G.C., Greene, David C., Walker, J.D., and Swanson, B.J., 1997, Paleozoic and Mesozoic evolution of east-central California: International Geology Review, 39, p. 788-829.

Sugarman, P.J., McCartan, L., Miller, K.G., Feigenson, M.D., Pekar, S., Kistler, R.W., and Robinson, A.G., 1997, Strontium-isotopic correlation of Oligocene to Miocene sequences, New Jersey and Florida, in Miller, K.G., and Snyder, S.W., eds., Proceedings of the Ocean Drilling Program, Scientific Results, v.150X: College Station, Tex., Ocean Drilling Program, p.147-159. 
Swanson, D.A., Moore, R.B., and Banks, N.G., 1997, Geologic map of the Packwood quadrangle, southern Cascade Range, Washington: U.S. Geological Survey Open-file Report 97-157, 18 p., scale 1:24,000.

U.S. Geological Survey, 1997, Aeromagnetic map of Santa Rosa and vicinity on parts of the Santa Rosa and San Francisco $1^{\circ}$ by $2^{\circ}$ quadrangles, California: U.S. Geological Survey Open-file Report 97-468, scale 1:250,000.

U.S. Geological Survey, 1997, "Wrestling with uncertainty"-the national assessment for oil and natural gas resources: U.S. Geological Survey Open-file Report 97855 , video.

Weber, F.R., Wheeler, K.L., Rinehart, C.D., and Light, T.D., 1997, Generalized geologic map of the Livengood quadrangle, Alaska: U.S. Geological Survey Open-file Report 97-484-A, scale 1:250,000.

Weber-Band, J., Williams, P.L., Jones, D.L., Johnson, P., and McEvilly, T.V., 1997, Active tectonic deformation at the eastern margin of the California Coast Ranges: results of the BASIX and Calcrust programs: U.S. Geological Survey Open-file Report 97-691, $17 \mathrm{p}$.

Weir, G.W., 1997, Preliminary geologic map of the Blue Ridge Reservoir quadrangle, Coconino County, Arizona: U.S. Geological Survey Open-file Report 94-271, scale 1:24,000.

Weir, G.W., and Beard, L.S., 1997, Preliminary geologic map of the Strawberry quadrangle, Yavapai, Gila, and Coconino counties, Arizona: U.S. Geological Survey Open-file Report 94-265, scale 1:24,000.

Wenrich, K.J., Billingsley, G.H., and Huntoon, P.W., 1997, Breccia pipe and geologic map of the northeastern part of the Hualapai Indian Reservation and vicinity, Arizona: U.S. Geological Survey Miscellaneous Investigations Series Map I2440 , scale $1: 48,000$.

Wentworth, C.M., Graham, S.E., Pike, R.J., Beukelman, G.S., Ramsey, D.W., and Barron, A.D., 1997, Summary distribution of slides and earth flows in the San Francisco Bay region, California: U.S. Geological Survey Open-file Report 97745-C, 10 p., <http://wrgis.wr.usgs.gov/open-file/of97-745/index.html>.

Wilson, R.C., and Jayko, A.S., 1997, Preliminary maps showing rainfall thresholds for debris-flow activity, San Francisco Bay region, California: U.S. Geological Survey Open-file Report 97-745-F, 20 p., <http://wrgis.wr.usgs.gov/open-file/of97-745/index.html>.

Wooden, J.L., Kistler, R.W., and Morton, D.M., 1997, Rb-Sr WR ages and Sr, O, and $\mathrm{Pb}$ isotopic systematics of plutons in the northern Peninsular Ranges batholith, 
southern California [abs.]: Geological Society of America Abstracts with Programs, v. 29, no. 5, p. 74.

Wooden, J.L., Kistler, R.W., Tosdal, R.M., Robinson, A., and Wright, J.E., 1997, Pb vs $\mathrm{Sr}$ isotopic mapping of crustal structure in the northern Great Basin [abs.]: Geological Society of America Abstracts with Programs, v. 29, no. 6, p. A-70.

Wooden, J.L., Tosdal, R.M., and Kistler, R.W., 1997, Pb and Sr isotopic mapping of crustal structure in the northern Great Basin, in Vikre, P., Thompson, T.B., Bettles, K., and Christensen, O., and Parratt, R., eds., Carlin-type gold deposits field conference: Society of Economic Geologists Guidebook Series, v. 28, p. 4753.

Yerkes, R.F., 1997, Preliminary geologic map of the Beverly Hills 7.5' quadrangle, southern California: U.S. Geological Survey Open-file Report 97-256, 9 p., scale $1: 24,000$.

Yerkes, R.F., 1997, Preliminary geologic map of the Burbank 7.5' quadrangle, southern California: a digital database: U.S. Geological Survey Open-file Report 97-166, 11 p., <http://wrgis.wr.usgs.gov/open-file/of97-166/index.html>.

Yerkes, R.F., 1997, Preliminary geologic map of the Hollywood 7.5' quadrangle, southern California: U.S. Geological Survey Open-file Report 97-255, 10 p., scale 1:24,000.

Yerkes, R.F., 1997, Preliminary geologic map of the Los Angeles 7.5' quadrangle, southern California: U.S. Geological Survey Open-file Report 97-254, 9 p., scale $1: 24,000$.

Yerkes, R.F., 1997, Preliminary geologic map of the Mint Canyon 7.5' quadrangle, southern California: a digital database: U.S. Geological Survey Open-file Report 97-164, 11 p., <http://wrgis.wr.usgs.gov/open-file/of97-164/index.html>.

Yerkes, R.F., 1997, Preliminary geologic map of the San Fernando 7.5' quadrangle, southern California: a digital database: U.S. Geological Survey Open-file Report 97-163, 11 p., <http://wrgis.wr.usgs.gov/open-file/of97-163/index.html>.

Yerkes, R.F., 1997, Preliminary geologic map of the Sunland 7.5' quadrangle, southern California: a digital database: U.S. Geological Survey Open-file Report 97-270, 11 p., <http://wrgis.wr.usgs.gov/open-file/of97-270/index.html>.

Yerkes, R.F., 1997, Preliminary geologic map of the Van Nuys 7.5' quadrangle, southern California: a digital database: U.S. Geological Survey Open-file Report 97-165, 11 p., <http://wrgis.wr.usgs.gov/open-file/of97-165/index.html>.

Yerkes, R.F., and Campbell, R.H., 1997, Preliminary geologic map of the Calabasas 7.5' quadrangle, southern California: a digital database: U.S. Geological Survey 
Open-file Report 95-51, 12 p., $<$ http://wrgis.wr.usgs.gov/open-file/of95-51/index.html>.

Yerkes, R.F., and Campbell, R.H., 1997, Preliminary geologic map of the Canoga Park 7.5' quadrangle, southern California: a digital database: U.S. Geological Survey Open-file Report 95-90, 11 p., <http://wrgis.wr.usgs.gov/open-file/of95-90/index.html>.

Yerkes, R.F., and Campbell, R.H., 1997, Preliminary geologic map of the Fillmore 7.5' quadrangle, southern California: a digital database: U.S. Geological Survey Open-file Report 95-802, 11 p., <http://wrgis.wr.usgs.gov/open-file/of95-802/index.html>.

Yerkes, R.F., and Campbell, R.H., 1997, Preliminary geologic map of the Malibu Beach 7.5' quadrangle, southern California: a digital database: U.S. Geological Survey Open-file Report 97-257, 11 p., <http://wrgis.wr.usgs.gov/open-file/of97-257/index.html>.

Yerkes, R.F., and Campbell, R.H., 1997, Preliminary geologic map of the Moorpark 7.5' quadrangle, southern California: a digital database: U.S. Geological Survey Open-file Report 97-260, 11 p., <http://wrgis.wr.usgs.gov/open-file/of97-260/index.html>.

Yerkes, R.F., and Campbell, R.H., 1997, Preliminary geologic map of the Newbury Park 7.5' quadrangle, southern California: U.S. Geological Survey Open-file Report 97-428, 9 p., scale 1:24,000.

Yerkes, R.F., and Campbell, R.H., 1997, Preliminary geologic map of the Newbury Park 7.5' quadrangle, southern California: a digital database: U.S. Geological Survey Open-file Report 97-459, 11 p., <http://wrgis.wr.usgs.gov/open-file/of97-459/index.html>.

Yerkes, R.F., and Campbell, R.H., 1997, Preliminary geologic map of the Newhall 7.5' quadrangle, southern California: a digital database: U.S. Geological Survey Open File Report 95-800, 11 p., <http://wrgis.wr.usgs.gov/open-file/of95-800/index.html>.

Yerkes, R.F., and Campbell, R.H., 1997, Preliminary geologic map of the Oat Mountain 7.5' quadrangle, southern California: a digital database: U.S. Geological Survey Open-file Report 95-89, 11 p., <http://wrgis.wr.usgs.gov/open-file/of95-89/index.html>.

Yerkes, R.F., and Campbell, R.H., 1997, Preliminary geologic map of the Piru 7.5' quadrangle, southern California: a digital database: U.S. Geological Survey Open-file Report 95-801, 11 p., <http://wrgis.wr.usgs.gov/open-file/of95-801/index.html>. 
Yerkes, R.F., and Campbell, R.H., 1997, Preliminary geologic map of the Point Dume 7.5' quadrangle, southern California: a digital database: U.S. Geological Survey Open File Report 97-276, 11 p., <http://wrgis.wr.usgs.gov/open-file/of97-276/index.html>.

Yerkes, R.F., and Campbell, R.H., 1997, Preliminary geologic map of the Santa Susana 7.5' quadrangle, southern California: a digital database: U.S. Geological Survey Open-file Report 97-258, 11 p., <http://wrgis.wr.usgs.gov/open-file/of97-258/index.html>.

Yerkes, R.F., and Campbell, R.H., 1997, Preliminary geologic map of the Simi 7.5' quadrangle, southern California: a digital database: U.S. Geological Survey Open-file Report 97-259, 11 p., <http://wrgis.wr.usgs.gov/open-file/of97-259/index.html>.

Yerkes, R.F., and Campbell, R.H., 1997, Preliminary geologic map of the Thousand Oaks 7.5' quadrangle, southern California: a digital database: U.S. Geological Survey Open-file Report 95-88, 11 p., <http://wrgis.wr.usgs.gov/open-file/of95-88/index.html>.

Yerkes, R.F., and Campbell, R.H., 1997, Preliminary geologic map of the Topanga 7.5' quadrangle, southern California: a digital database: U.S. Geological Survey Open-file Report 95-91, 11 p., $<$ http://wrgis.wr.usgs.gov/open-file/of95-91/index.html>.

Yerkes, R.F., and Campbell, R.H., 1997, Preliminary geologic map of the Val Verde 7.5' quadrangle, southern California: a digital database: U.S. Geological Survey Open-file Report 95-699, 11 p., <http://wrgis.wr.usgs.gov/open-file/of95-699/index.html>.

Yerkes, R.F., and Campbell, R.H., 1997, Preliminary geologic map of the west half, Los Angeles 60' x 30' quadrangle: U.S. Geological Survey Open-file Report 97-483, scale $1: 100,000$

Yerkes, R.F., and Graham, S.E., 1997, Preliminary geologic map of the Beverly Hills 7.5' quadrangle, southern California: a digital database: U.S. Geological Survey Open-file Report 97-430, 11 p., <http://wrgis.wr.usgs.gov/open-file/of97-430/index.html>.

Yerkes, R.F., and Graham, S.E., 1997, Preliminary geologic map of the Hollywood 7.5' quadrangle, southern California: a digital database: U.S. Geological Survey Open File Report 97-431, 11 p., <http://wrgis.wr.usgs.gov/open-file/of97-431/index.html>.

Yerkes, R.F., and Graham, S.E., 1997, Preliminary geologic map of the Los Angeles 7.5' quadrangle, southern California: a digital database: U.S. Geological Survey Open-file Report 97-432, 11 p., <http://wrgis.wr.usgs.gov/open-file/of97-432/index.html>. 
Zhaimina, V.Y., Zhemchuzhnikov, V.G., Cook, H.E., Buvtyshkin, V.M., Golub, L.Y.M., Zempolich, W.G., Kotova, E.A., Viaggi, M., Lehmann, P.J., Giovannelli, A., Lapointe, P., and Bowman, M., 1997, Biostratigraphic succession of a 4,500 meter thick upper Paleozoic carbonate platform: Bolshoi Karatau Mountains, southern Kazakhstan [abs.], in Ross, C.A., Ross, J.R.P., and Brenkle, P.L., eds., Late Paleozoic foraminifera: their biostratigraphy, evolution, and paleoecology and the mid-Carboniferous boundary: Cushman Foundation for Foraminiferal Research, Special Publication no. 36, p. 169-170.

Zempolich, W.G., Cook, H.E., Zhemchuzhnikov, V.G., Zorin, A.Ye., Giovannelli, A., Viaggi, M., and Zhaimina, V.Ya., 1997, The role of biotic and abiotic constituents in the development and diagenesis of middle to late Paleozoic carbonate platforms: outcrop and subsurface examples from the C.I.S. [abs.]: 1997 AAPG Annual Convention, Official Program, v. 6, p. A129.

\section{PUBLICATIONS}

Aiello, I.W., and Hagstrum, J.T., 1998, Paleomagnetism of Jurassic radiolarian chert sequences of the Mediterranean region: a progress report [abs.]: Eos, American Geophysical Union, Transactions, v. 79, no. 45, supplement, p. F224-F225.

Anderson, T.B., and Stanley, R.G., 1998, Field trip road log: geology and tectonics of the Gualala block, in Elder, W.P., ed., Geology and tectonics of the Gualala block, northern California: Los Angeles, Calif., Pacific Section, SEPM, Book 84, p. 213-222.

Beard, L.S., 1998, Strain-partitioning in a mixed strike-slip/extensional faulting regime: an example from the Virgin Mountains, Nevada-Arizona [abs.]: Geological Society of America Abstracts with Programs, v. 30, no. 6, p. 3.

Bedford, D.R., and Miller, D.M., 1998, A first-generation decision support system: geology for Mojave Desert Ecosystem planning [abs.]: Geological Society of America Abstracts with Programs, v. 30, no. 5, p. 5.

Behl, R.J., and Ingle, J.C., Jr., 1998, The Sisquoc Formation-Foxen Mudstone boundary in the Santa Maria Basin, California: sedimentary response to the new tectonic regime, chap. V of Keller, M.A., ed., Evolution of sedimentary basins/onshore oil and gas investigations-Santa Maria Province: U.S. Geological Survey Bulletin 1995, p. V1-V16.

Billingsley, G.H., 1998, Grand Canyon, in Kamilli, R.J., and Richard, S.M., eds., Geologic highway map of Arizona: Tuscon, Ariz., Arizona Geological Society and Arizona Geological Survey, scale 1:1,000,000.

Billingsley, G.H., 1998, Paleo Permian/Triassic river systems of northwestern Arizona [abs.]: Geological Society of America Abstracts with Programs, v. 30, no. 6, p. 4. 
Bird, K.J., 1998, Oil and gas potential of the Arctic National Wildlife Refuge (ANWR) revisited [abs.]: AAPG Annual Convention, Salt Lake City, Utah, May 17-20, 1998, Extended Abstract no. A67, 1 p.

Blakely, R.J., 1998, Introduction to geomagnetic fields (book review): Eos, Transactions, American Geophysical Union, v. 79, no. 12, p. 153.

Blakely, R.J., Morin, R.L., McKee, E.H., Schmidt, K.M., Langenheim, V.E., and Dixon, G.L., 1998, Three-dimensional model of Paleozoic basement beneath Amargosa Desert and Pahrump Valley, California and Nevada: implications for tectonic evolution and water resources: U.S. Geological Survey Open-File Report 98496, $29 \mathrm{p}$.

Blakely, R.J., Wells, R.E., and Finn, C.A., 1998, Geometry and deformation of the Cascadia forearc: implications from high-resolution aeromagnetic surveys and gravity measurements [abs.]: Eos, Transactions, American Geophysical Union, v. 79 , no. 24 , supplement, p. W118.

Blakely, R.J., Wells, R.E., Haugerud, R.A., Pratt, T., and Weaver, C.S., 1998, Geometry and deformation of the Cascadia forearc: implications from a new high-resolution aeromagnetic survey of the Puget lowland, Washington [abs.]: Eos, Transactions, American Geophysical Union, v. 79, no. 45, supplement, p. F873.

Blakely, R.J., Wells, R.E., Weaver, C.S., Johnson, S.Y., and Dadisman, S.V., 1998, Structure and seismicity of the Seattle fault [abs.]: Eos, Transactions, American Geophysical Union, v. 79, no. 45, supplement, p. F874.

Block, D., and Morgan, P., 1998, Diffusional flow law in landscape evolution along the southern Rocky Mountains [abs.]: Geological Society of America Abstracts with Programs, v. 30, no. 6, p. 4-5.

Brabb, E.E., Graymer, R.W., and Jones, D.L., 1998, Geology of the onshore part of San Mateo County, California: a digital database: U.S. Geological Survey Open-file Report 98-137, 9 p., <http://wrgis.wr.usgs.gov/open-file/of98-137/index.html>.

Brabb, E.E., Graymer, R.W., and Jones, D.L., 1998, Geology of the Palo Alto 30 × 60minute quadrangle, California: a digital database: U.S. Geological Survey Open-file Report 98-348, 16 p., <http://wrgis.wr.usgs.gov/open-file/of98-348/index.html>.

Brabb, E.E., Jones, D.L., and Wentworth, C.M., 1998, Regional relations of Paleocene and Eocene strata of the Gualala Block [abs.]: American Association of Petroleum Geologists Bulletin, v. 82, no. 5A, p. 843. 
Bukry, D., Brabb, E.E, Powell, C.L., II, Jones, D.L., and Graymer, R.W., 1998, Recent Tertiary and Cretaceous nannoplankton collections from the San Francisco Bay region: U.S. Geological Survey Open-file Report 98-497, 33 p.

Campbell, R.H., 1998, Probabilistic debris-flow hazard maps [abs.]: Eos, Transactions, American Geophysical Union, v. 79, no. 45, supplement, p. F292-293.

Cole, R.B., and Stanley, R.G., 1998, Volcanic rocks of the Santa Maria Province, California, chap. R of Keller, M.A., ed., Evolution of sedimentary basins/onshore oil and gas investigations-Santa Maria Province: U.S. Geological Survey Bulletin 1995, p. R1-R35.

Cox, B.F., 1998, Late Cretaceous and early Paleogene tectonics and sedimentation near the Garlock Fault, California-did Neogene strike-slip faulting exploit an older structural zone?, in Calzia, J.P., and Reynolds, R.E., eds., Finding faults in the Mojave: San Bernardino County Museum Quarterly, v. 45, no. 1/2, p. 45-51.

Cox, B.F., Hillhouse, J.W., Sarna-Wojcicki, A.M., and Tinsley, J.C., III, 1998, PliocenePleistocene depositional history along the Mojave River north of Cajon Pass, California-regional tilting and drainage reversal during uplift of the central Transverse Ranges [abs.]: Geological Society of America Abstracts with Programs, v. 30, no. 5, p. 11.

Dawson, M.L., Morton, D.M., Kistler, R.W., Lichte, F.E., and Jachens, R.C., 1998, A GIS analysis of the Lakeview Mountains pluton [abs.]: Geological Society of America Abstracts with Programs, v. 30, no. 5, p. 11.

Elder, W.P., Saul, L.R., and Powell, C.L., II, 1998, Late Cretaceous and Paleogene molluscan fossils of the Gualala Block and their paleogeographic implications, in Elder, W.P., ed., Geology and tectonics of the Gualala Block, northern California: Los Angeles, Calif., Pacific Section, SEPM, Book 84, p. 149-168.

Fitzgibbon, T.T., 1998, Taking geographic information systems to the field: laptops, palmtops, GPS, and lots of batteries! [abs.]: Geological Society of America Abstracts with Programs, v. 30, no. 5, p. 14.

Fleck, R.J., Theodore, T.G., Sarna-Wojcicki, A.M., and Meyer, C.E. 1998, Age and possible source of air-fall tuffs of the Miocene Carlin Formation, northern Nevada, in Tosdal, R.M., ed., Contributions to the gold metallogeny of northern Nevada: U.S. Geological Survey Open-file Report 98-338, p. 176-192.

Graham, S.E., and Pike, R.J., 1998, Elevation maps of the San Francisco Bay region, California: a digital database: U.S. Geological Survey Open-file Report 98-625, 17 p., <http://wrgis.wr.usgs.gov/open-file/of98-625/index.html>.

Graham, S.E., and Pike, R.J., 1998, Slope maps of the San Francisco Bay region, California: a digital database: U.S. Geological Survey Open-file Report 98-766, 17 p., <http://wrgis.wr.usgs.gov/open-file/of98-766/index.html>. 
Grommé, S., 1998, Magnetic properties and paleomagnetism of the La Perouse and Astrolabe Gabbro intrusions, Fairweather Range, southeastern Alaska, in Gray, J.E., and Riehle, J.R., eds., Geologic studies in Alaska by the U.S. Geological Survey, 1996: U.S. Geological Survey Professional Paper 1595, p. 99-115.

Hagstrum, J.T., and Jones, D.L., 1998, Paleomagnetism, paleogeographic origins, and uplift history of the Coast Range ophiolite at Mount Diablo, California: Journal of Geophysical Research, v. 103, no. B1, p. 597-603.

Hagstrum, J.T., and Murchey, B.L., 1998, Paleomagnetic studies indicate that red radiolarian cherts of the Marin Headlands terrane were deposited at the earth's equator [abs.]: First Symposium on Current Natural Research in Golden Gate National Recreation Area, Fort Mason, San Francisco, v. 1, p. 20.

Hagstrum, J.T., and Sedlock, R.L., 1998, Remagnetization of Cretaceous forearc strata on Santa Margarita and Magdalena Islands, Baja California Sur: implications for northward transport along the California margin: Tectonics, v. 17, no. 6, p. 872882.

Hagstrum, J.T., and Sedlock, R.L., 1998, Remagnetization of Cretaceous forearc strata on Santa Margarita and Magdalena Islands, Baja California Sur: implications for northward transport along the California margin [abs.]: Eos, American Geophysical Union, Transactions, v. 79, no. 45, supplement, p. F220.

Hagstrum, J.T., Swanson, D.A., and Snee, L.W., 1998, Paleomagnetism of the Miocene intrusive suite of Kidd Creek: timing of deformation in the Cascade arc, southern Washington: Journal of Geophysical Research, v. 103, no. B9, p. 21,047-21,056.

Hampton, H.M., and Billingsley, G.H., 1998, Geographic information system techniques for displaying geologic features in the Grand Canyon region [abs.]: Geological Society of America Abstracts with Programs, v. 30, no. 6, p. 10.

Haugerud, R.A., 1998, Geologic maps, spatial databases, and standards, in Soller, D.R., ed., Digital mapping techniques '98 - Workshop proceedings: U.S. Geological Survey Open-file Report 98-487, p. 41-46, <http://ncgmp.usgs.gov/pubs/of98-487intro.html>.

Haugerud, R.A., and Greenberg, H.M., 1998, Recipes for digital cartography: cooking with DEM's, in Soller, D.R., ed., Digital mapping techniques '98 - Workshop proceedings: U.S. Geological Survey Open-file Report 98-487, p. 119-126, <http://ncgmp.usgs.gov/pubs/of98-487intro.html>.

Haugerud, R.A., Yelin, T.S., Ludwin, R.S., and Wells, R.E., 1998, Physiography and seismicity of Cascadia (30N-53N, 133W-116W) [abs.]: Eos, Transactions, American Geophysical Union, v. 79, no. 24, supplement, p. W118. 
Hereford, R., Burke, K.J., and Thompson, K.S., 1998, Map showing Quaternary geology and geomorphology of the Nankoweap Rapids area, Marble Canyon, Arizona:

U.S. Geological Survey Geologic Investigations Series Map I-2608, scale $1: 2,000$.

Highland, L.M., Godt, J., Howell, D., and Savage, W.Z., 1998, El Niño 1997-98: Damaging landslides in the San Francisco Bay area: U.S. Geological Survey Fact Sheet FS-089-98, 2 p.

Hudson, M.R., Rosenbaum, J.G., Grommé, S., Scott, R.B., and Rowley, P.D., 1998, Paleomagnetic evidence for counterclockwise rotation in a broad sinistral shear zone, Basin and Range province, southeastern Nevada and southwestern Utah, in Faulds, J.E., and Stewart, J.H., eds., Accommodation zones and transfer zones: the regional segmentation of the Basin and Range province: Geological Society of America Special Paper 323, p. 149-180.

Irwin, W.P., and Mankinen, E.A., 1998, Rotation and accretionary evolution of the Klamath Mountains, California and Oregon, from Devonian to present time: U.S. Geological Survey Open-file Report 98-114, 1 sheet, <http://wrgis.wr.usgs.gov/open-file/of98-114/index.html>.

Jachens, R.C., and Calzia, J.P., 1998, A geophysical analysis of the Garlock Fault, in Calzia, J.P., and Reynolds, R.E., eds., Finding faults in the Mojave: San Bernardino County Museum Association Quarterly, v. 45, no. 1/2, p. 36-41.

Jachens, R.C., Langenheim, V.E., Chuchel, B.A., Morton, D.M., and Dawson, M.L., 1998, Three-dimensional geology in the southern California Areal Mapping Project based on geologic mapping and geophysical interpretations [abs.]: Geological Society of America Abstracts with Programs, v. 30, no. 5, p. 21.

Jachens, R.C., Wentworth, C.M., and McLaughlin, R.J., 1998, Constraints from potential field anomalies on offset histories of faults bounding the Gualala block [abs.]: American Association of Petroleum Geologists Bulletin, v. 82, no. 5A, p. 849.

Jachens, R.C., Wentworth, C.M., and McLaughlin, R.J., 1998, Pre-San Andreas location of the Gualala block inferred from magnetic and gravity anomalies, in Elder, W.P., ed., Geology and tectonics of the Gualala block, northern California: Los Angeles, Calif., Pacific Section, SEPM, Book 84, p. 27-64.

Jayko, A.S., Rymer, M.J., Prentice, C.S., Wilson, R.C., and Wells, R.E., 1998, Scenic Drive landslide of January-March 1998, La Honda, San Mateo County, California: U.S. Geological Survey Open-file Report 98-229, 1 sheet.

Johnson, S.Y., Dadisman, S.V., Mosher, D.C., Blakely, R.J., Childs, J.R., and Wells, R.E., 1998, Neotectonics of the eastern Strait of Juan de Fuca region, northwestern Washington and southwestern British Columbia [abs.]: Eos, Transactions, American Geophysical Union, v. 79, no. 45, supplement, p. F897. 
Jones, D.L., Wentworth, C., and Brabb, E.E., 1998, Structural development of the Gualala block, northern California [abs.]: American Association of Petroleum Geologists Bulletin, v. 82, no. 5A, p. 850.

Keller, M.A., and Bird, K.J., 1998, Challenges of petroleum source rock evaluation using sonic and resistivity logs and the delta Log $\mathrm{R}$ method, northeastern Alaska [abs.]: American Association of Petroleum Geologists Bulletin, v. 82, no. 5A, p. 850.

Kistler, R.W., 1998, Strontium and oxygen isotopic investigations of igneous rocks in the northwestern Mojave Desert, southern California [abs.]: Geological Society of America Abstracts with Programs, v. 30, no. 5, p. 24.

Langenheim, V.E., Beyer, L.A., McCulloh, T.H., Brocher, T.M., Murphy, J., Fuis, G.S., and Jachens, R.C., 1998, Basins and basement of southern California from gravity modeling and well, rock-density and seismic-refraction data: a progress report [abs.]: Geological Society of America Abstracts with Programs, v. 30, no. 5 , p. 49-50.

Langenheim, V.E., Grow, J., Miller, J., Davidson, J.D., and Robison, E., 1998, Thickness of Cenozoic deposits and location and geometry of the Las Vegas Valley shear zone, Nevada, based on gravity, seismic-reflection, and aeromagnetic data: U.S. Geological Survey Open-file Report 98-576, 32 p.

Matti, J.C., Kennedy, S.A., Miller, F.K., Powell, R.E., and Cossette, P.M., 1998, Digital geologic-map data-base architecture for the USGS/CDMG Southern California Areal Mapping Project: some hands-on prototypes [abs.]: Geological Society of America Abstracts with Programs, v. 30, no. 5, p. 53.

Matti, J.C., Powell, R.E., and Miller, F.K., 1998, The Blackhawk Mountain massif, southern California: a Quaternary folded-thrust uplift in the left-stepping Helendale fault zone? [abs.]: Geological Society of America Abstracts with Programs, v. 30 , no. 5 , p. 53.

Matti, J.C., Powell, R.E., and Miller, F.K., 1998, The San Bernardino Mountains of southern California: a Quaternary fold-, thrust-, and tear-fault belt [abs.]: Geological Society of America Abstracts with Programs, v. 30, no. 5, p. 53.

McDougall, K., 1998, Late Neogene marine incursion and the ancestral Gulf of California [abs.]: Sociedad Mexicana de Paleontologia, I.A.C., Special Publication (July 5, 1998), v. 9, p. 68.

McDougall, K., 1998, Paleoceanography and correlation of late Quaternary glaciomarine units in Washington [abs.]: Sociedad Mexicana de Paleontologia, I.A.C., Special Publication (July 5, 1998), v. 9, p. 68-69.

McDougall, K., 1998, Paleogene foraminifera of the Gualala block and their relation to local and global events, in Elder, W.P., ed., Geology and tectonics of the Gualala 
block, northern California: Los Angeles, Calif., Pacific Section, SEPM, Book 84, p. 169-188.

McDougall, K., 1998, Tertiary microfaunas of the Gualala and Pt. Arena basins and their relation to local and global events [abs.]: American Association of Petroleum Geologists Bulletin, v. 82, no. 5A, p. 853.

McKee, E.H., and Conrad, J.E., 1998, Geologic map of the Frazier Creek quadrangle, Nevada: Nevada Bureau of Mines and Geology, Field Studies Map 15, scale 1:24,000.

McKee, E.H., Wickham, T.A., and Wheeler, K.L., 1998, Evaluation of faults and their effect on ground-water flow southwest of Frenchman Flat, Nye and Clark Counties, Nevada: a digital database: U.S. Geological Survey Open-file Report 98-580, 14 p., <http://wrgis.wr.usgs.gov/open-file/of98-580/index.html>.

McLaughlin, R.J., Jachens, R.C., Wentworth, C.M., McDougall, K., Sliter, W.V., and Elder, W.P., 1998, Pre-Miocene locations of Gualala and Sierra Azul blocks, northern California [abs.]: American Association of Petroleum Geologists Bulletin, v. 82, no. 5A, p. 853.

Miller, D., Negrini, R., McGuire, M., Huggins, C., Minner, M., Hacker, B., SarnaWojcicki, A., Meyer, C., and Fleck, R., 1998, New upper age constraint on the Kern River formation, in Reid, T., ed., San Joaquin Geological Society Fall field trip: San Joaquin Geological Society, p. 23-26a.

Miller, D.M., and Bedford, D.R., 1998, Geomorphic history from geologic mapping of the El Mirage (dry) Lake area, western Mojave Desert, San Bernardino County, California [abs.]: Geological Society of America Abstracts with Programs, v. 30, no. 5 , p. 55.

Miller, F.K., Matti, J.C., Brown, H.J., Powell, R.E., Cosette, P.M., and Morton, G., 1998, Digital geologic map of the Fawnskin 7.5' quadrangle, San Bernardino County, California: U.S. Geological Survey Open-file Report 98-579, 18 p., $<$ http://wrgis.wr.usgs.gov/open-file/of98-579/index.html>.

Miller, F.K., Matti, J.C., and Powell, R.E., 1998, The Fawnskin quadrangle, first product of a cooperative geologic mapping project between the Southern California Areal Mapping Project (SCAMP) and the U.S. Forest Service [abs.]: Geological Society of America Abstracts with Programs, v. 30, no. 5, p. 55.

Morin, R.L., Blakely, R.J., McKee, E.H., Schmidt, K.M., Langenheim, V.E., and Dixon, G.L., 1998, Three-dimensional model of pre-Cenozoic basement beneath Amargosa Desert and Pahrump Valley, California and Nevada: implications for tectonic evolution and water resources [abs.]: Eos, Transactions, American Geophysical Union, v. 79 , no. 45, supplement, p. F807. 
Nielson, J.E., 1998, Geologic map of the East of Grotto Hills 7.5 minute quadrangle, California: U.S. Geological Survey Open-File Report 98-469, 4 p., scale $1: 24,000$.

Nielson, J.E., and Turner, R.D., 1998, Geologic map of the Hart Peak 7.5 minute quadrangle, California and Nevada: U.S. Geological Survey Open-file Report 98-470, 12 p., scale 1:24,000.

Parsons, T., Wells, R., Fisher, M., Brocher, T., Trehu, A., Flueh, E., Miller, K., and ten Brink, U., 1998, Peeking into Cascadia's basement: results of seismic profiling 1995-1998 [abs.]: Eos, Transactions, American Geophysical Union, v. 79, no. 45, supplement, p. F873.

Pike, R.J., 1998, Web resources compiled for terrain modeling: Eos, Transactions, American Geophysical Union, v. 79. no. 17, p. 208, <http://www.agu.org/eos_elec/97260e.html>.

Pike, R.J., and 16 others, 1998, Slope failure and shoreline retreat around San Francisco Bay in the El Niño winter of 1997-98 [abs.]: Eos, Transactions, American Geophysical Union, v. 79, no. 45, supplement, p. F292.

Pike, R.J., and Thomas, T.R., 1998, Quantitative characterization of microtopography-a bibliography of industrial surface metrology: U.S. Geological Survey Open-file Report 98-768, 145 p.

Ponce, D.A., 1998, Drill-hole lithology map of the Winnemucca 1:250,000 quadrangle, Nevada: U.S. Geological Survey Open-file Report 98-220, scale 1:250,000.

Ponce, D.A., 1998, Isostatic gravity map of the Beatty and the western part of the Indian Springs 1:100,000-scale quadrangles, Nevada: U.S. Geological Survey Open-file Report 98-250, scale 1:100,000.

Ponce, D.A., Hildenbrand, T.G., Jachens, R.C., Roberts, C.W., and Fahringer, P.E., 1998, Gravity and magnetic anomalies along the Hayward fault and their relation to earthquake seismicity, California [abs.]: Eos, Transactions, American Geophyscial Union, v. 79, no. 45, supplement, p. F594.

Powell, C.L., II, 1998, The Purisima Formation and related rocks (upper Miocene Pliocene), greater San Francisco Bay area, central California: review of literature and USGS collections (now housed at the Museum of Paleontology, University of California, Berkeley): U.S. Geological Survey Open-file Report 98-594, 103 p.

Powell, R.E., and Matti, J.C., 1998, Stratigraphic and geomorphic relations between the Mojave Desert and San Bernardino Mts. piedmont, Lucerne Valley, CA: Part I [abs.]: Geological Society of America Abstracts with Programs, v. 30, no. 5, p. 59. 
Powell, R.E., and Matti, J.C., 1998, Stratigraphic and geomorphic relations between the Mojave Desert and San Bernardino Mts. piedmont, Lucerne Valley, CA: Part II [abs.]: Geological Society of America Abstracts with Programs, v. 30, no. 5, p. 59.

Ramirez, P.C., and Garrison, R.E., 1998, Stratigraphy of the fine-grained facies of the Sisquoc Formation, Santa Maria Basin, California-paleoceanographic and tectonic implications, chap. U of Keller, M.A., ed., Evolution of sedimentary basins/onshore oil and gas investigations-Santa Maria Province: U.S. Geological Survey Bulletin 1995, p. U1-U15.

Rigsby, C.A., 1998, Paleogeography of the western Transverse Range province, California: new evidence from the late Oligocene and early Miocene Vaqueros Formation, chap. T of Keller, M.A., ed., Evolution of sedimentary basins/onshore oil and gas investigations-Santa Maria Province: U.S. Geological Survey Bulletin 1995, p. T1-T18.

Roberts, C.W., Blakely, R.J., Beyer, L.A., and Benz, H.M., 1998, A three-dimensional view of Long Valley Caldera, California [abs.]: Eos, Transactions, American Geophysical Union, v. 79, no. 45, supplement, p. F962.

Roberts, M.A., Chan, C.S., Howell, D.G., Wentworth, C.M., and Jachens, R.C., 1998, 3-D geologic maps [abs.]: AAPG Annual Convention, Salt Lake City, Utah, May 17-20, 1998, Extended Abstract no. A557, 4 p.

Roberts, S., Barron, A., Brabb, E.E., and Pike, R.J., 1998, Digital compilation of "Preliminary map of landslide deposits in Santa Cruz County, California, by Cooper-Clark and Associates, 1975": a digital map database: U.S. Geological Survey Open-file Report 98-792, 22 p., <http://wrgis.wr.usgs.gov/open-file/of98-792/index.html>.

Romanyuk, T.V., Blakely, R.J., and Mooney, W.D., 1998, The Cascadia subduction zone: two contrasting models of lithospheric structure: Physics and Chemistry of the Earth, v. 23, no. 3, p. 297-301.

Sarna-Wojcicki, A.M., 1998, Appendix H, in Wakeley, L.D., Murphy, W.L., Dunbar, J.B., Warne, A.G., Briuer, F.L., and Nickens, P.R., Geologic, geoarcheologic, and historical investigation of the discovery site of ancient remains in Columbia Park, Kennewick, Washington: U.S. Army Corps of Engineers, Technical Report GL98-13, p. H1-H17.

Sarna-Wojcicki, A.M., 1998, Tephrochronology, in Sowers, J.M., Noller, J.S., and Lettis, W.R., eds., Dating and earthquakes: review of Quaternary geochronology and its application to paleoseismology: U.S. Nuclear Regulatory Commission, NUREG5562, Chapter 2.7.2, p. 2-569-2-596.

Sowers, J.M., Noller, J.S., and Lettis, W.R., 1998, Quaternary geology and liquefaction susceptibility, Napa, California 1:100,000 quadrangle: a digital database: U.S. 
Geological Survey Open-file Report 98-460, 12 p., <http://wrgis.wr.usgs.gov/open-file/of98-460/index.html>.

Stanley, R.G., Jachens, R.C., Lillis, P.G., McLaughlin, R.J., Kvenvolden, K.A., Hostettler, F.D., and Magoon, L.B., 1998, Subsurface geology, Neogene tectonics, and petroleum of the southwestern Santa Clara Valley ("Silicon Valley"), California [abs.]: American Association of Petroleum Geologists Bulletin, v. 82, no. 5a, p. 859.

Stanley, R.G., Stone, P., Vedder, J.G., McDougall, K.A., Kellogg, K.S., Minor, S.A., and Premo, W.R., 1998, New 1:24,000-scale geologic mapping in the Cuyama $30 \mathrm{x}$ 60-min. sheet, southern Coast Ranges and western Transverse Ranges, Calif. [abs.]: Geological Society of America Abstracts with Programs, v. 30, no. 5, p. 65-66.

Stewart, J.H., Anderson, R.E., Aranda-Gomez, J.J., Beard, L.S., Billingsley, G.H., Cather, S.M., Dilles, J.H., Dokka, R.K., Faulds, J.E., Ferrari, L., Grose, T.L.T., Henry, C.D., Janecke, S.U., Miller, D.M., Richard, S.M., Rowley, P.D., RoldanQuintana, Jaime, Scott, R.B., Sears, J.W., and Williams, V.S., 1998, Map showing Cenozoic tilt domains and associated structural features, western North America, in Faulds, J.E., and Stewart, J.H., eds., Accommodation zones and transfer zones: the regional segmentation of the Basin and Range province: Geological Society of America Special Paper 323. plate 1, scale 1:5,000,000.

Swanson, B.J., Dunne, G.C., Stone, P., Conrad, J.E., and Stevens, C.H., 1998, Geology of the Cerro Gordo 7.5' quadrangle, southern Inyo Mountains: a new window into the Phanerozoic structural evolution of east-central California [abs.]: Geological Society of America Abstracts with Programs, v. 30, no. 5, p. 68.

Taylor, B.E., McKee, E.H., and Sillitoe, R.H., 1998, American meteoric waters: stable isotope compositions and implications for Andean uplift [abs.]: Geological Society of America Abstracts with Programs, v. 30, no. 7, p. A318.

Thorstenson, D.J., and Beard, L.S., 1998, Using structural geologic analysis to facilitate environmental and hydrologic site investigations of the Camp Navajo Arizona Army National Guard Facility, Bellemont, Arizona [abs.]: Geological Society of America Abstracts with Programs, v. 30, no. 6, p. 38.

U.S. Geological Survey, 1998, Secrets in stone: U.S. Geological Survey Open-file Report 98-27, video.

Vedder, J.G., Stanley, R.G., McLean, H., Cotton, M.L., Filewicz, M.V., and York, D.R., 1998, Age and tectonic inferences of a condensed(?) succession of Upper Cretaceous, Paleocene, and Eocene strata, Big Pine Mountain area, Santa Barbara County, California, chap. S of Keller, M.A., ed., Evolution of sedimentary basins/onshore oil and gas investigations-Santa Maria Province: U.S. Geological Survey Bulletin 1995, p. S1-S33. 
Weaver, C.S., Yelin, T.S., Meagher, K.L., Wells, R.E., and Blakely, R.J., 1998, Crustal earthquakes in Cascadia: evidence for North American plate block tectonics [abs.]: Eos, Transactions, American Geophysical Union, v. 79, no. 45, supplement, p. F874.

Wells, M.L., Hoisch, T.D., Peters, M.T., Miller, D.M., Wolff, E.D., and Hanson, L.M., 1998, The Mahogany Peaks fault, a Late Cretaceous-Paleocene(?) normal fault in the hinterland of the Sevier orogen: Journal of Geology, v. 106, no. 5, p. 623634.

Wells, R.E., Blakely, R.J., and Weaver, C.S., 1998, Tectonics and earthquake potential of Cascadia: effects of rotation and northward transport of fore-arc crustal blocks in Oregon and Washington [abs.]: Eos, Transactions, American Geophysical Union, v. 79, no. 24, p. W115.

Wells, R.E., Weaver, C.S., and Blakely, R.J., 1998, Cascadia fore-arc migration and its neotectonic significance [abs.]: Eos, Transactions, American Geophysical Union, v. 79, no. 45, supplement, p. F874.

Wells, R.E., Weaver, C.S., and Blakely, R.J., 1998, Fore-arc migration in Cascadia and its neotectonic significance: Geology, v. 26, no. 8, p. 759-762.

Wentworth, C.M., Jones, D.M., Brabb, E.E., and Elder, W.P., 1998, Regional relations of the Mesozoic rocks of the Gualala Block, northern California [abs.]: American Association of Petroleum Geologists Bulletin, v. 82, no. 5A, p. 861.

Wooden, J.L., Kistler, R.W., Fleck, R.J., Morton, D.M., and Barth A.P., 1998, Pb and Sr isotopic and age contrasts among the geologic terranes in southern California: a tool for understanding range uplift, basin development and tectonic evolution [abs.]: Geological Society of America Abstracts with Programs, v. 30, no. 5, p. 71.

Wooden, J.L., Kistler, R.W., and Tosdal, R.M., 1998, Pb isotopic mapping of crustal structure in the northern Great Basin and relationships to Au deposit trends, in Tosdal, R.M., ed., Contributions to the gold metallogeny of northern Nevada: U.S. Geological Survey Open-file Report 98-338, p. 20-33.

Yerkes, R.F., Campbell, R.H., and Graham, S.E., 1998, Digital geologic map of the Los Angeles 60 ' by 30 ' quadrangle [abs.]: Geological Society of America Abstracts with Programs, v. 30, no. 5, p. 71. 